\title{
Persian Language
}

National Cancer Institute

\section{Source}

National Cancer Institute. Persian Language. NCI Thesaurus. Code C153916.

A Western Iranian language within the Indo-Iranian branch of the Indo-European

language family primarily spoken in Iran, Afghanistan, and Tajikistan. 